\title{
Hubungan antara pH Darah dengan Kadar Laktat Dehidrogenase pada Asfiksia Neonatorum
}

Leny Angkawijaya, Rocky Wilar, Johnny Rompis, Helene Aneke Tangkilisan, Suryadi N.N.Tatura

Bagian Ilmu Kesehatan Anak Fakultas Kedokteran Universitas Sam Ratulangi / BLU RSU Prof. Dr. R. D. Kandou, Manado

Latar belakang. Asfiksia neonatorum dapat menyebabkan keadaan asidemia yang mengakibatkan terjadinya kerusakan sel. Kerusakan sel dapat dilihat dengan peningkatan kadar laktat dehidrogenase (LDH). Banyak kasus asfiksia neonatorum, tetapi belum banyak yang meneliti tentang hubungan $\mathrm{pH}$ darah dengan kadar LDH.

Tujuan. Mengetahui hubungan antara $\mathrm{pH}$ darah dengan kadar LDH pada asfiksia neonatorum.

Metode. Penelitian dengan desain potong lintang pada asfiksia neonatorum. Pengambilan sampel secara consecutive, bayi asfiksia dilakukan pemeriksaan LDH dan $\mathrm{pH}$ darah. Kriteria inklusi adalah bayi cukup bulan, berat badan $\geq 2500$ gram, mendapat persetujuan orang tua. Kriteria eksklusi adalah kelainan kongenital mayor, tersangka sepsis, trauma lahir, ibu sectio caesarea (SC) dengan anestesi umum.

Hasil. Jumlah subjek 45 bayi, didapatkan 25 bayi asfiksia dengan LDH normal dan 20 dengan LDH meningkat, rerata LDH yang meningkat 1045,95 dan $\mathrm{pH} 7,17$. Nilai korelasi Pearson antara $\mathrm{pH}$ darah dan kadar LDH darah $-0,649(\mathrm{p}=<0,001)$, yang berarti memiliki hubungan negatif.

Kesimpulan. Pada bayi asfiksia neonatorum, semakin turun nilai $\mathrm{pH}$ darah maka kadar LDH semakin meningkat.

Sari Pediatri 2015;17(2):141-4.

Kata kunci: asfiksia neonatorum, $\mathrm{pH}$ darah, $\mathrm{LDH}$

\section{Relationship Between Blood pH with Lactate Dehydrogenase in Neonatal Asphyxia}

Leny Angkawijaya, Rocky Wilar, Johnny Rompis, Helene Aneke Tangkilisan, Suryadi NN Tatura

Background. Neonatal asphyxia can cause acidemia circumstances which result in cell damage. Cell damage can be seen with increased levels of lactate dehydrogenase ( LDH ). Many cases of neonatal asphyxia but not much research on the relationship with the blood $\mathrm{pH}$ levels of $\mathrm{LDH}$.

Objective. To determine the relationship between blood $\mathrm{pH}$ with LDH levels in neonatal asphyxia .

Methods. A cross-sectional study design in neonatal asphyxia. Consecutive sampling, infant asphyxia examination LDH and blood $\mathrm{pH}$. Inclusion criteria : term infants, weight $\geq 2500$ grams, approved by parents. Exclusion criteria : major congenital abnormalities, suspect sepsis, birth trauma, maternal sectio caesarea ( SC ) with general anesthesia

Results. The number of samples of 45 infants, 25 infants asphyxia obtained with normal LDH and 20 infants with increased LDH, LDH increased average 1045.95 and a $\mathrm{pH}$ of 7.17. Pearson correlation values between blood $\mathrm{pH}$ and blood LDH level of -0.649 with $\mathrm{p}=<0.001$, which means it has a negative relationship .

Conclusions. In infants neonatal asphyxia has lowered the $\mathrm{pH}$ value of the blood levels of LDH increase.

Sari Pediatri 2015;17(2):141-4.

Keywords: neonatal asphyxia, blood $\mathrm{pH}, \mathrm{LDH}$ Alamat korespondensi: Dr. Leny Angkawijaya, Sp.A. Bagian IKA FK UNSRAT - BLU RSUP Prof. Dr. R.D. Kandou. Jl. Raya Tanawangko
Malalayang. E-mail: leny_angkawijaya@idai.or.id, laurabigailulaan@yahoo.com 
A sfiksia neonatorum adalah suatu stres pada janin atau bayi baru lahir karena kurang tersedia oksigen dan atau aliran darah (perfusi) ke berbagai organ kurang. ${ }^{1}$ Dampak dari keadaan asfiksia tersebut adalah hipoksia, hiperkarbia, dan asidemia yang akan meningkatkan pemakaian sumber energi dan mengganggu sirkulasi bayi. ${ }^{2,3}$ Hipoksia yang berkelanjutan menyebabkan kekurangan oksigen untuk menghasilkan energi bagi metabolisme tubuh sehingga terjadi proses glikolisis anerobik. Produk sampingan proses tersebut adalah asam laktat dan piruvat yang menimbulkan peningkatan asam organik tubuh yang berakibat menurunnya $\mathrm{pH}$ darah sehingga terjadilah asidosis metabolik. ${ }^{4,5}$

Penurunan $\mathrm{pH}$ darah arteri dapat digunakan sebagai alat yang dapat menentukan tingkat oksigenasi dan kondisi asam basa pada janin. Secara klinis, penurunan $\mathrm{pH}$ darah <7,00 menimbulkan asidosis yang berat, tetapi kerusakan sel karena hipoksia belum tentu terjadi. ${ }^{6}$

Kerusakan dari sel dapat dilihat dengan pemeriksaan kadar laktat dehidrogenase (LDH). Pengukuran LDH pada bayi asfiksia dengan kerusakan sel organ karena hipoksia dan iskemik lebih efektif dari pada pengukuran laktat. Pada semua jaringan terdapat LDH dan merupakan petanda dari kerusakan sel. Penggunaan biomarker seperti LDH yang meningkat pada neonatus dapat membantu dalam diagnosis dini terjadinya kerusakan sel otak, seperti hypoxic ischaemic encephalopathy (HIE). ${ }^{7,8}$

Penelitian sebelumnya melaporkan tentang kerusakan tingkat selular pada neonatus yang mengalami asfiksia dengan menggunakan $\mathrm{LDH}$ sebagai prediktor terjadinya HIE pada bayi baru lahir. Peningkatan kadar LDH pada bayi dengan HIE ditemukan saat 12 jam postpartum (HIE telah terjadi). ${ }^{9}$ Studi klinis terdahulu menunjukkan bahwa kadar LDH meningkat pada bayi asfiksia yang baru lahir dalam jam pertama kehidupan. ${ }^{10}$

Penelitian tentang hubungan $\mathrm{pH}$ darah dengan LDH pada bayi asfiksia belum banyak dilakukan. Tujuan dari penelitian ini untuk mengetahui apakah ada hubungan antara $\mathrm{pH}$ darah dengan $\mathrm{LDH}$ pada bayi asfiksia neonatorum.

\section{Metode}

Dilakukan penelitian observasional analitik dengan desain potong lintang di Sub Bagian Neonatologi
RSUP Prof. Dr. R.D. Kandou Manado. Sampel penelitian adalah bayi asfiksia neonatorum yang diambil secara consecutive. Kriteria inklusi adalah bayi cukup bulan, berat badan lahir $\geq 2500 \mathrm{~g}$, dan mendapat persetujuan orang tua. Kriteria eksklusi adalah kelainan kongenital mayor (penyakit jantung bawaan, atresia esophagus, hernia diafragmatika, gastroschisis), tersangka sepsis, trauma lahir, dan ibu SC dengan general anestesi.

Pemeriksaan serum LDH dilakukan pada saat bayi baru lahir dengan skor APGAR 0-3 pada menit kelima postpartum bersamaan dengan pemeriksaan $\mathrm{pH}$ darah yang dilakukan dengan menggunakan alat analisis gas darah. Pengambilan darah untuk analisis gas darah dilakukan melalui arteri umbilikal dan LDH melalui vena umbilikal (dengan kateter umbilikal). Untuk pH darah diperlukan 1 cc darah dengan menggunakan tabung heparin dan $\mathrm{LDH}$ 2 cc menggunakan tabung serum. Diagnosis dari asfiksia neonatorum menggunakan American Academy of Pediatrics (AAP) dan the American College of Obstetricians and Gynecologists (ACOG) membuat definisi asfiksia perinatal jika terdapat, (1) asidosis metabolik atau mixed acedemia $(\mathrm{pH}<7,00)$ pada darah umbilikus atau analisis gas darah arteri, (2) skor Apgar 0-3 yang menetap selama $>5$ menit, (3) manifestasi neurologis segera pada waktu perinatal dengan gejala kejang, hipotonia, koma, HIE, dan (4) gangguan fungsi multiorgan segera pada waktu perinatal. Dari empat kriteria tersebut, harus ada satu atau lebih dalam mendefinisikan asfiksia. ${ }^{11}$ Kadar LDH pada neonatus $>580$ adalah tidak normal.

Penelitian dilakukan dari bulan September 2013Desember 2013. Analisis data menggunakan analisis bivariat. Oleh karena distribusi data normal, uji hipotesis dilakukan dengan uji korelasi Pearson. Data yang dikumpulkan diolah dengan menggunakan program SPSS versi 22. Penelitian ini telah mendapat persetujuan dari Komite Etik Fakultas Kedokteran Universitas Sam Ratulangi.

\section{Hasil}

Pemeriksaan laboratorium kadar LDH darah ditemukan 20 (45\%) bayi yang mengalami asfiksia dengan kadar LDH yang meningkat (LDH > 580 U/L), dan 25 (55\%) kadar LDH normal ( $\leq 580 \mathrm{U} / \mathrm{L})$. Pada bayi asfiksia dengan kadar LDH yang tidak meningkat didapatkan 
$\mathrm{pH}$ rerata 7,29 (IK95\%: 7,28-7,31), sedangkan bayi asfiksia dengan kadar LDH yang meningkat didapatkan pH rerata 7,03 (IK95\%: 6,82-7,20). Rerata peningkatan kadar LDH adalah 1065,70 U/L (IK95\%: 889,101242,30). Hubungan antara $\mathrm{pH}$ dan kadar $\mathrm{LDH}$ tertera pada Gambar 1. Scatterplot menyatakan bahwa semakin turun nilai $\mathrm{pH}$ darah maka kadar LDH darah semakin meningkat. Nilai korelasi Pearson antara $\mathrm{pH}$ darah dan kadar LDH darah $-0,649(\mathrm{p}=<0,001)$. Jadi, terdapat hubungan yang kuat dan bermakna antara nilai $\mathrm{pH}$ darah dan kadar LDH darah dan memiliki hubungan yang negatif.

Tabel 1. Karakteristik subyek penelitian

\begin{tabular}{lc}
\hline Variabel & Bayi asfiksia \\
\hline Usia gestasi (minggu) & $39-40(48,9 \%)$ \\
Jenis kelamin, n (\%) & \\
Laki-laki & $21(46,7)$ \\
Perempuan & $24(54,3)$ \\
Berat badan lahir (gram) & \\
Rerata & 3190 \\
Median & 3200 \\
Minimum & 2500 \\
Maksimum & 4000 \\
\hline
\end{tabular}

LDH

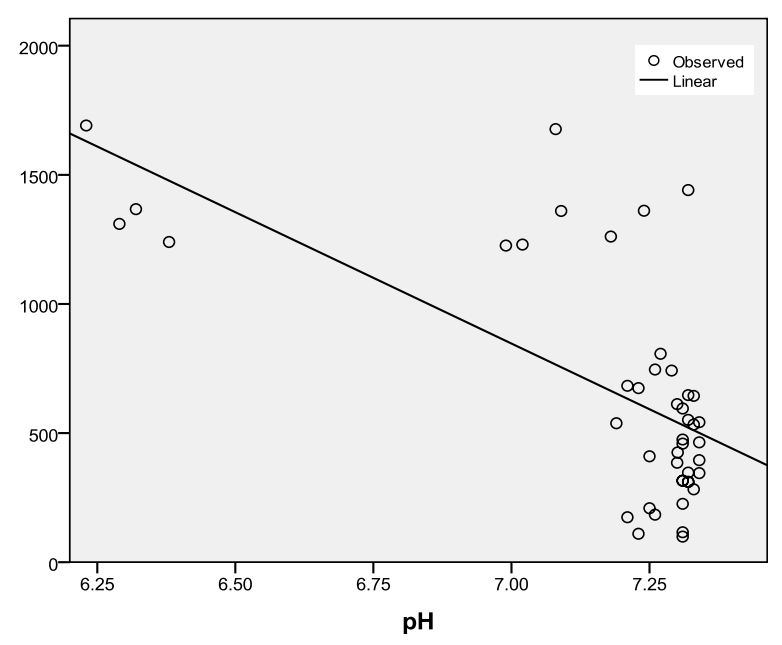

Gambar 1. Scatterplot hubungan nilai pH darah dengan kadar $\mathrm{LDH}$ pada bayi asfiksia neonatorum.

\section{Pembahasan}

Kami mendapatkan bahwa $45 \%$ bayi yang mengalami asfiksia memiliki kadar $\mathrm{LDH}$ yang tinggi ( $>580 \mathrm{U} / \mathrm{L})$ dengan rerata kadar LDH 1065,70 U/L dengan rerata $\mathrm{pH}$ darah 7,03. Di samping itu, juga didapatkan $\mathrm{pH}$ darah yang rendah, tetapi memiliki kadar LDH yang normal. Hal tersebut dapat disebabkan bayi mengalami asfiksia, tetapi belum sampai terjadi kerusakan sel yang dapat menyebabkan terjadinya kerusakan organ sehingga tidak terjadi peningkatan dari kadar LDH.

Karlson $\mathrm{dkk}^{13}$ meneliti peningkatan LDH pada 12 jam bayi asfiksia neonatorum yang baru lahir, menemukan bayi yang mengalami HIE dan non HIE. Lackman $\mathrm{dkk}^{14}$ menyimpulkan bahwa bayi baru lahir dengan asfiksia memiliki nilai kadar $\mathrm{LDH}$ yang meningkat secara signifikan $>580 \mathrm{U} / \mathrm{L}$ pada bayi asfiksia neonatorum dan tidak mengubah kadar enzim LDH dan akan meningkat setelah terjadi kerusakan organ. Studi di Sri Lanka oleh Karunatilaka dkk ${ }^{15}$ melaporkan hasil yang sama, yaitu terjadi peningkatan kadar LDH pada 6 jam kehidupan. Hal yang sama juga ditunjukkan oleh Sanchez-Nava dkk ${ }^{16}$ yang meneliti kadar AST, ALT, dan LDH yang meningkat pada bayi asfiksia. Hasil penelitian kami memperlihatkan bahwa pada sebagian bayi asfiksia sudah terjadi kerusakan sel pada satu jam postpartum.

Kerusakan sel menyebabkan kebocoran enzim intraselular yang dapat diukur di dalam plasma seperti LDH..${ }^{16}$ Sebelumnya, enzim ini pernah dilaporkan akan meningkat setelah terjadi asfiksia neonatal-sampel darah diambil pada tali pusat setelah lahir. Laktat dehidrogenase memiliki sensitivitas tertinggi (100\%), spesifisitas (98\%), dan nilai prediktif $(90 \%)$ untuk HIE berat. ${ }^{17,18}$

Semakin lama dan berat asfiksia yang terjadi, semakin berat dan banyak organ yang mengalami hipoksia disfungsi organ dan akhirnya mengalami kematian sel atau jaringan. ${ }^{19} \mathrm{Hal}$ tersebut dapat dilihat dari scatterplot hubungan $\mathrm{pH}$ darah dengan kadar $\mathrm{LDH}$, bahwa semakin rendah nilai $\mathrm{pH}$ (hipoksia berlangsung) semakin meningkat kadar dari LDH. Laktat dehidrogenase bisa dijadikan alat prediktor awal

Tabel 2. Hasil laboratorium darah bayi asfiksia

\begin{tabular}{lllll}
\hline Laboratorium & Rerata & Median & SB & IK95\%: dari rerata \\
\hline $\mathrm{pH}$ & 7,17 & 7,30 & 0,28 & $7,09-7,26$ \\
$\mathrm{LDH}$ & 663,02 & 538,00 & 452,74 & $527,00-799,04$ \\
\hline
\end{tabular}


bayi asfiksia neonatorum yang baru lahir. Pemeriksaan LDH merupakan prediktor awal pada kerusakan sel organ yang disebabkan oleh hipoksia iskemik atau prediktor sebelum terjadi kerusakan otak. ${ }^{20}$

\section{Kesimpulan}

Dapat disimpulkan bahwa terdapat hubungan antara penurunan nilai $\mathrm{pH}$ darah dengan peningkatan kadar LDH pada asfiksia neonatorum. Dengan demikian, kadar LDH meningkat pada bayi yang mengalami asfiksia dapat memberikan informasi dalam menegakkan diagnosis asfiksia neonatorum serta penanganan selanjutnya.

\section{Daftar pustaka}

1. Gomella TL, Cunningham D, Eyal FG. Neonatology management, procedures, on-call problems, diseases, drugs. Edisi ke-7. Connecticut: Lange;2009.h.624-33.

2. Wayenberg JL, Dramaix N, Vermeylen D, Bormans J, Pardou A. Neonatal out come after birth asphyxia: early indicators of prognosis. Prenat Neonat Med 2009;3:482-9.

3. Thorp JA. What is birth asphyxia? Am J Obstet Gynecol 1990;163:1367-8.

4. Indarso F. Dampak jangka panjang bayi asfiksia. Disampaikan pada Kongres Nasional Ilmu Kesehatan Anak XI, Jakarta, 4-7 Juli 2009.h.547-57.

5. Roberton NRC. A manual of neonatal intensive care. Edisi ke-3. Cambridge: Edward Arnold; 2009.h.72-6.

6. Cloherty JP, Stark AR, penyunting. Manual of neonatal care. Edisi ke-4. Philadelphia: Williams \& Wilkins; 1998.h.515-33.

7. Westgren M, Divon M, Horal M, Ingemarsson I, Kublickas M, Shimojo N, dkk. Routine measurements of umbilical artery lactate levels in the prediction of perinatal outcome. Am J Obstet Gynecol 1995;173:1416-22.

8. Gomella TL, Cunningham MD, Eyal FG, Zenk KE. Perinatal asphyxia. Dalam: Gomella TL, Cunningham MD, Eyal FG, Zenk KE, penyunting. Neonatology management, procedures, on-call problems, diseases, and drugs. Edisi ke-5. New York: Lange medical books McGraw Hill; 2004.h.208-11.

9. Karlsson M, Blennow M, Nemeth A, Winbladh B.
Dynamics of hepatic enzyme activity following birth asphyxia. Acta Pediatr 2006;95:1405-11.

10. Varsani M, Xanthos T, Aroni F, Argyri I, Lelovas P, Dontas I, dkk. Inflamation and oxidative stress biomarkers in neonatal brain hypoxia and prediction of adverse neurological outcome: a review. Italy. J Pediatr Neonat Individual Med 2013;2:1-14.

11. World Health Organization. Basic newborn resuscitation: a practical guide-revision. Geneva: World Health Organization; 2008. Di akses pada 16 Agustus 2015. Diunduh dari: http://www.who.int/reproductivehealth/pub/ newborn_resus_citation/index.html

12. Nicholson JF, Perce MA. Reference ranges for laboratory tests and procedures. Dalam: Behrman RE, Kliegman RM, Jenson HB, penyunting. Nelson textbook of Pediatrics. Edisi ke-17. Philadelphia: Saunders; 2004.h.2396-427.

13. Karlsson M, Wiberg-Itzel E, Chakkarapani E, Blennow M, Winbladh B, Thoresen M. Lactate dehydrogenase predicts hypoxic ischaemic encephalopathy in newborn infants: a preliminary study. Acta Pediatr 2010;99:1139-44.

14. Lackmann GM, Tollner U, Mader R. Serum enzyme activities in full-term asphyxiated and healthy newborns: enzyme kinetics during the first 144 hours of life. Enzyme Protein 1993; 47:160-72.

15. Karunatilaka DH, Amaratunga GWDS, Perera KDNI, Caldera V. Serum creatine kinase and lactic dehydrogenase levels as useful markers of immediate and long term outcome of perinatal asphyxia. Sri Lanka J Child Health 2000;29:49-52.

16. Sanchez NJ, Gonzalez CS, Hernandez M, Renteria MA. Increase in glutamic oxaloacetic and glutamic pyruvic transaminase and lactic dehydrogenase as a diagnostic aid in perinatal asphyxia. Bol Med Hosp Infant Mex 1990;47:372-5.

17. Brooks, G. A. The lactate shuttle in nature. New York: Oxford University; 2009.h.319-30.

18. Douglas-Escobar M, Weiss MD. Biomarkers of brain injury in the infant. Front Neurol 2012;3:185.

19. Victory R, Penova D, Da Silva O. Umbilical cord $\mathrm{pH}$ and base excess values in relation to adverse outcome events for infants delivering at term. Am J Obstet Gynecol 2004;191:2021-8.

20. Reddy S, Dutta S, Narang A. Evaluation of lactate dehydrogenase, creatinine kinase and hepatic enzymes for the retrospective diagnosis of perinatal asphyxia among sick neonates. Indian Pediatr 2008;45:144-7. 